\title{
Trafik Kaynaklı Ağır Metal Kirliliklerinin İzlenmesinde Zeytin Ağacının (Olea europaea L.) Biyomonitör Olarak Değerlendirilmesi: Artvin Örneği
}

\author{
Mustafa Umut Konanç ${ }^{1, *}$ (i) \\ ${ }^{1}$ Artvin Çoruh Üniversitesi, Artvin Meslek Yüksekokulu, Kimya ve Kimyasal İşleme Teknolojileri Bölümü, 08100, Artvin. \\ Özet
}

Bu çalışmada trafik yoğunluğundan kaynaklanan ă̆ır metal konsantrasyonunun izlenmesinde zeytin ă̆acının (Olea eurpaea L.) biyomonitör olarak kullanılma potansiyeli araștırılmıștır. Bu amaçla Artvin ili kent merkezinde trafik yoğunluğunun farklı olduğu altı farklı istasyondan toplanan toprak, yaprak, meyve ve kabuk örneklerindeki \% kükürt miktarl, elementel analiz cihazı ile Cr, Ti, Fe, Ni, $\mathrm{Co}, \mathrm{Cu}, \mathrm{Zn}, \mathrm{Pb}$ ve Al içerikleri ise ICP-OES ile belirlenmiștir. Analiz ölçümlerinin doğruluğu toprak örnekleri için LGC 6187 ve bitki örnekleri için ERM-CD 281 standart referans madde kullanılarak test edilmiștir. Elde edilen ölçüm sonuçlarındaki farklılıklar ise ANOVA testi kullanllarak belirlenmiştir. Elde edilen sonuçlara göre; toprak, yaprak, meyve ve kabukta yüzdesel olarak en yüksek kükürt değeri trafik yoğunluğunun en fazla olduğu noktalarda tespit edilmiştir. Bitki ve toprak örneklerindeki $\mathrm{Cr}, \mathrm{Ti}, \mathrm{Fe}, \mathrm{Ni}, \mathrm{Co}, \mathrm{Cu}$, $\mathrm{Zn}, \mathrm{Pb}$ ve Al elementleri için ağır metal konsantrasyonları yapılan diğer çalışmalar ve yönetmeliklerle karşılaştırılmış ve tüm metallerin sınır değeler içerisinde bulunduğu gözlenmiștir. Yapılan istatiksel çalıșmalarda; noktalar arasında \%95 güven düzeyinde anlamlı bir fark olduğu belirlenmiștir. Ayrica trafiğin yoğun olduğu alanlardan uzaklaştıkça toprak, yaprak, meyve ve kabuğun metal konsantrasyonlarında azalma olduğu tespit edilmiştir. Bu durum zeytinin trafik kaynakl kirliliğin belirlenmesinde biyomonitör olarak kullanılabileceğini göstermektedir.

Anahtar Sözcükler

Ağır Metal, Biyomonitör, Zeytin, Çevre Kirliliği

\section{Evaluation of Olive Tree (Olea europaea L.) as A Biomonitor for Monitoring of Heavy Metal Pollution Caused by Traffic: Example of Artvin}

\begin{abstract}
In this study, the potential of using olive tree (Olea europaea L.) as a biomonitor was investigated in monitoring heavy metal concentrations caused by traffic density. For this reason, in soil, leaf, fruit and shell samples collected from regions where traffic density is different in the city center of Artvin province, Sulfur content (\%) was determined by elemental analyzer and heavy metals $(\mathrm{Cr}, \mathrm{Ti}, \mathrm{Fe}, \mathrm{Ni}, \mathrm{Co}, \mathrm{Cu}, \mathrm{Zn}, \mathrm{Pb}$ and $\mathrm{Al}$ ) was determined by ICP-OES. The accuracy of the assay measurements was tested using LGC 6187 for soil samples and ERM-CD 281 for plant samples. The differences in the measurement results obtained were determined using the ANOVA test According to the results obtained; the highest sulfur value in soil, leaves, fruit and bark was determined at the points with the highest traffic density. Heavy metal concentrations for $\mathrm{Cr}, \mathrm{Ti}, \mathrm{Fe}, \mathrm{Ni}, \mathrm{Co}, \mathrm{Cu}, \mathrm{Zn}, \mathrm{Pb}$ and Al elements in plant and soil samples were compared with other studies and regulations, and all metals were found to be within the limit values. In statistical studies, it has been determined that there is a significant difference between points at 95\% confidence level. In addition, it has been found that metal concentrations of soil, leaves, fruits and bark decrease as they move away from traffic areas. This is an indication that olives can be used as biomonitors in detecting traffic pollution.
\end{abstract}

$\underline{\text { Keywords }}$

Heavy Metals, Biomonitor, Olive, Environment Pollution

\section{Giriş}

Hızla artan dünya nüfusu ile birlikte endüstri ve sanayileşmeye olan talep artmakta; ekosistemde yer alan doğal kaynakların hızlı ve bilinçsizce tüketiminin bir sonucu olarak yaşamsal kaynaklar günden güne azalmaktadır. Ekosistem üzerinde yaşamsal faaliyetlerin sürdürülebilir olması için üç temel bileşenden hava, su ve toprağın kontrolsüz ve yanlış kullanımı sonucunda çevresel problemler karşımıza çıkmakta ve yaşamsal alanlar her geçen gün sınırlanmaktadır. İnsan kaynaklı bu çevresel problemlerin temelinde; plansız kentleșme, hızlı sanayileşme, organik ve inorganik kaynaklı atıklar ve bilinçsizce kullanılan tarımsal ilaçlar gibi birçok etken sayılabilir (Sayılı ve Akman 1994). Bu etkenlerin kontrolsüz kullanımın doğaya yansıması su, hava ve toprak kirliliği olarak karşımıza çıkmaktadır. 
Toprak kirliliği; toprağın sahip olduğu fiziksel, kimyasal ve biyolojik özelliklerin geri dönüşümsüz olarak yitirilmesi olarak ifade edilebilir (Karaca ve Turgay 2012). Su kirliliği; su kaynaklarının, fiziksel, kimyasal, bakteriyel ve radyolojik açıdan belirlenen sınır değerleri aşması ve artan konsantrasyonlara bağlı olarak ekolojik özelliklerinin olumsuz yönde değişimi olarak tanımlanmaktadır (Yanık ve Atamanalp 2001). Hava kirliliği; atmosferde azot oksitlerin $\left(\mathrm{NO}_{\mathrm{x}}\right)$, kükürt dioksitlerin $\left(\mathrm{SO}_{2}\right)$, partikül maddelerin $(\mathrm{PM})$ ve karbon türevlerinin belirlenen sınır değerin üzerinde derişim göstermesi şeklinde ifade edilebilir (Bayram vd. 2006).

Toprak, su ve havanın kontrolsüzce kirletilmesi sonucu doğal yapısının kısmen ve tamamen değişmesine yol açan birçok kirletici unsur bulunmaktadır. Bu kirletici unsurlardan çoğunlukla eser miktarda bulunan ve kimyasal kirlilik olarak adlandırılan gruplar arasında ağır metaller önemli bir yer tutmaktadır (Mater 1998).

A ğır metaller genel olarak, periyodik tabloda atom ağırlıkları bakımından 63.55 ile bakır elementinden başlayan ve 200.59 atom ağırlığı ile civa elementi ile sonlanan; özgül ağırlıkları $4 \mathrm{~g} / \mathrm{cm}^{3}$ 'den büyük olan elementler olarak adlandırılır (Altın 2002). Bu metallerin ekosfere yayılımında; endüstriyel faaliyetler, motorlu taşıtlar, madensel faaliyetler, tarımsal ilaçlamalar ve kentsel atıklar gibi birçok kaynak yer almaktadır (Sresty ve Rao 1999). Biyosferde etkin olarak yer alan bu eser elementlerin biyolojik proseslere katılımı ise gereklilik ve toksik olarak iki sınıfa ayrılmaktadır. Canlı organizmada belli konsantrasyonlarda bulunan ve organizmanın temel yapı taşları arasında yer alan ağır metaller olduğu gibi, besinler yoluyla alınabilen ve canlı organizmada toksik etki gösteren ağır metallerde mevcuttur. Örneğin bakır canlı organizmalarda oksidasyon, redoksiyon ve kırmızı kan hücrelerinin oluşumunda yer alırken, eser düzeyde civa kükürtlü enzimlerle bağlanarak beyinden, böbreklere kadar birçok organa zarar verebilir (Bingham vd. 2001). Ağır metal kaynaklı kirlenmelerin canlı ekosisteme katılımında endüstriyel gelişmelere bağlı olarak motorlu taşıt kirliliği önemli bir yer tutmaktadır. Özellikle insan kaynaklı popülasyonun yüksek olduğu şehirlerde motorlu taşıt sayısı günden güne artmaktadır. Türkiye İstatistik Kurumu (TUIK 2019) verilerine göre Türkiye'de toplam motorlu taşıt sayısı 23156975 olarak hesaplanmıștır. Yine TUIK Trabzon Bölge Müdürlügü’nün 2019 Haziran verileri incelendiğinde Artvin için toplam araç sayısı 388874 olarak karşımıza çıkmaktadır. Bu durum 2018 yılı verileriyle kıyaslandığında $\% 1.7$ oranında bir artış gözlenmiştir. Özellikle yaz aylarında artan nüfusa paralel olarak ağır metal kirliliğinde $\mathrm{Ti}, \mathrm{Pb}, \mathrm{Cd}, \mathrm{Ni}, \mathrm{Cr}, \mathrm{Cu}$ ve $\mathrm{Zn}$ gibi eser elementler düşük konsantrasyonlarda yayllım göstermektedir. Bu düşük konsantrasyonlardaki metal iyonlarının canlı organizmada zamanla birikimi ile sınır değerler aşılmakta ve toksik etkiler karşımıza çıkmaktadır. Bu toksik etkilerin atmosferdeki değişiminin takibinde günümüzde birçok yöntem kullanılmaktadır. Bu yöntemlerden birisi de biyomonitör ile ağır metal birikimin takibidir. Biyomonitör olarak kullanılan bitkiler; toprak ve havadaki ağır metallerin bir kısımlarını bünyelerine absorbe ederek ekosistem zinciri üzerinden canlı organizmalara kadar metal taşınımı sağlayabilmektedir. Bu metal absorpsiyonu toprakta artan konsantrasyonlara bağlı olarak köklerde olabildiği gibi bitkinin diğer organalleri olan yapraklarda, meyve ve çiçeklerde de görülebilmektedir (Bondada vd. 2004). Biyomonitör olarak kullanılan türler arasında mantarlar, likenler, yosunlar, yıllık bitkiler ve yüksek yapılı çok yıllık ağaca kadar birçok tür yer almaktadır (Barnes vd. 1976) Bu türler arasında özellikle kentsel alanlar ve otoyol kenarlarında biyomonitör olarak kullanılan bitkileri için genel tercih her daim yeşil kalan ve çok yıllık bitki türleridir. Bu çok yıllık bitki türleri arasında bölgenin coğrafi konumu ve bitki florası göz önüne alındığında biyomonitör olarak bölgede geniş bir yayılım alanına sahip olan zeytin tercih edilmiştir.

Zeytin, Oleaceace familyasından gelmektedir. Bu familya içeresinde birçok tür yer almaktadır. Bu türler dünyada 27 çeşit; takson olarak ise 600 civarında yayılıma sahiptir Türkiye içerisinde yayılış alanı; coğrafi özellikler ve optimum iklim şartlarına bağlı olarak \%57.3 Ege Bölgesi, \%26.5 Akdeniz Bölgesi, \%11.1 Marmara Bölgesi, \%4.7 Güneydoğu Anadolu Bölgesi, \%0.4 Karadeniz bölgesi olarak sıralanmaktadır (Efe vd. 2009). Karadeniz bölgesinde toplam zeytin ağac1 390000 civarında olup Artvin, Trabzon, Samsun ve Sinop'ta sadece lokal alanlarda ürün yetiştirilmektedir. Bu yetiştirilen ürünlerin \%77 ise küçük aile işletmelerinde sofralık zeytin üretiminde kullanılmaktadır. Çalışmanın yapıldığı Artvin ilinde toplam 4240 dekar alanda zeytin tarımı yapılmakta ve 1426 ton zeytin ve 70 ton zeytinyağ 1 üretimi gerçekleşmektedir. Ancak Deriner Barajının faaliyete girmesi ile tarımsal hasat alanı 1000 dekar civarlarına kadar düşüş göstermiştir.

Besin içeriği bakımından zeytinin kimyasal bileşenlerine bakıldığında önemli bir kısmı su ve yağdan oluşmakta birlikte protein, selüloz, şeker, mineral maddeler, hidrokarbonlar ve fenolik bileşenler temel yapı içerisinde yer almaktadır. Özellikle kimyasal kompozisyon içerisinde yer alan ve eser miktarda olmasına karşın antioksidan özellik gösteren fenolik bileşenler oksidadif stabilite ve besin değeri açısından önemli bir yer tutmaktadır (Kiritsakis 1998). Zeytin ağacı temelde meyvenin direk olarak tüketimi veya zeytinyağı üretiminde hammadde kaynağı olarak kullanılmaktadır. Bununla birlikte zeytinyağı üretiminde zeytin keki (Prina), karasu, ince dallar ve yapraklar gibi yan ürünlerde büyük miktarda oluşmaktadır. Dolayısıyla zeytin yapră̆ zeytinin toplanmasında, budanmasında ve yağ olarak işleme basamaklarında toplam zeytin ağırlığının \%10 kadarlık kısmı olarak ortaya çıkmaktadır. Zeytin yapraklarının yapısında bulunan fenolik bileşenlerin (oleuropein, verbaskosit, ligrosit gibi fenolik glikozitler ile flavonoidler, flavonol glikozitleri, antosiyaninler ve glikozitleri, fenolik asitler) antioksidan, antifungal ve antibakteriyel özelliklere sahip olması gıda ürünlerde aktif olarak kullanılabilme imkanı ortaya çıkarmaktadır (Ferreire vd. 2007; Keçeli ve Gordon 2002). Bu kapsamda yapılan çalışmada; Artvin ili merkez ilçede coğrafi yayılış gösteren zeytin (Olea europaea L.)'in trafik kaynaklı kirliliğinin tespitinde biyomonitör olarak kullanılabilirliği araştırılmıştır. 
Bu kapsamda trafik akışının yoğun olduğu beş farklı istasyon noktası ve trafik kaynaklı kirlilikten uzak bir kontrol noktasından alınan zeytin (Olea europaea L.) bitkisinin toprak, yaprak, meyve ve kabuk kısımlarındaki Cr, Ti, Fe, Ni, $\mathrm{Co}, \mathrm{Cu}, \mathrm{Zn}, \mathrm{Pb}, \mathrm{Al}$ ve Mn konsantrasyonları ICP-OES ile ölçülmüş ve çıktılar istatiksel olarak değerlendirilmiştir

\section{Materyal ve Yöntem}

\section{1. Çalışma Alanının Belirlenmesi ve Numunelerin Toplanması}

Çalışma alanının belirlenmesinde bölgenin coğrafi konumunda yayılış gösteren ve ekonomik bir değere sahip olan zeytin (Olea europaea L.) bitkisinin meyvelerinin gıda kaynaklı tüketim için kullanılması, çok yıllık bir bitki olması ve her mevsim yeşil kalması avantajları dikkate alınarak biyomonitör olarak kullanılmasına karar verilmiştir. Bu amaçla Şekil 1'de görüldüğü üzere Artvin ili merkez ilçesinde ana arter üzerinde bulunan ve trafik yoğunluğunun fazla olduğu 5 istasyon ölçüm noktası olarak seçilmiştir. Ayrıca numunelerin trafik kaynaklı kirliliklerinin etkilerinin en az olduğu bir istasyon kontrol noktası olarak belirlenmiştir. Eylül 2019 yılında GPS konumları Tablo 1'de verilmiş olan 6 istasyon üzerindeki zeytin bitkisi için odaklanmış örneklem yöntemi kullanılmış ve rastgele örnekleme yöntemi ile toprakların 5 farklı noktasından (0-10 cm derinlikten) kompozit örnekleme yapılmıştır. Aynı bitkilerin 6 istasyonundan zeytin yaprakları ve meyve örnekleri rastgele örnekleme modeli kullanılarak alınmış ve tüm örnekler steril kilitli poşetlere aktarılarak aynı gün içerisinde laboratuvara taşınmıştır (Aksoy vd. 1999).

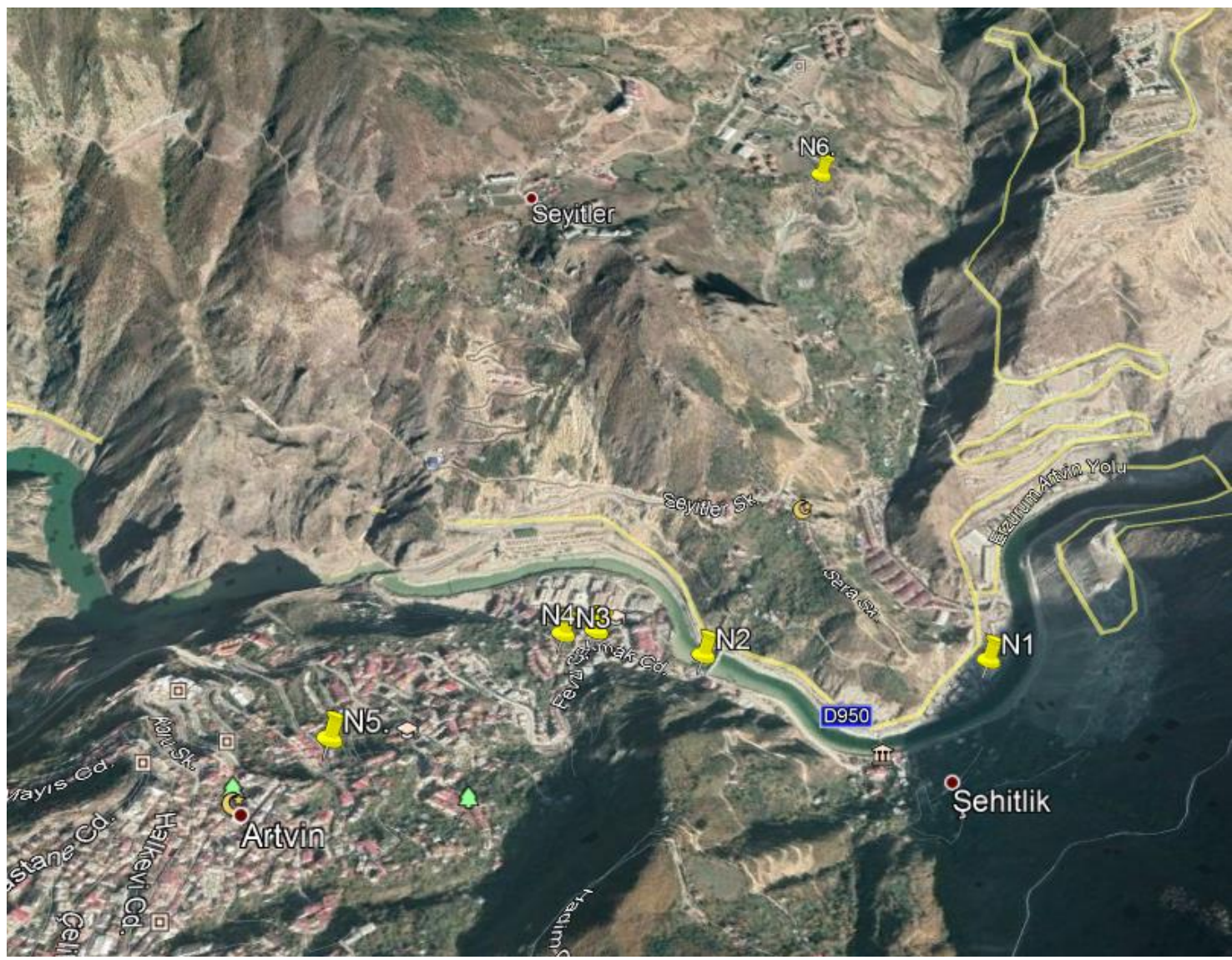

Şekil 1: Artvin ili yol ağı ve örneklem noktaları

Tablo 1: Örnek istasyonların coğrafi konumları

\begin{tabular}{c|c}
\hline İstasyon numarası & Coğrafi konum (enlem, boylam) \\
\hline $\mathrm{N} 1$ & $41^{\circ} 10.660^{\prime} \mathrm{N}-41^{\circ} 50.601^{\prime} \mathrm{E}$ \\
$\mathrm{N} 2$ & $41^{\circ} 10.881^{\prime} \mathrm{N}-41^{\circ} 50.110^{\prime} \mathrm{E}$ \\
$\mathrm{N} 3$ & $41^{\circ} 11.014^{\prime} \mathrm{N}-41^{\circ} 49.885^{\prime} \mathrm{E}$ \\
$\mathrm{N} 4$ & $41^{\circ} 10.997 ' \mathrm{~N}-41^{\circ} 49.946^{\prime} \mathrm{E}$ \\
$\mathrm{N} 5$ & $41^{\circ} 10.931^{\prime} \mathrm{N}-41^{\circ} 49.409^{\prime} \mathrm{E}$ \\
$\mathrm{N} 6$ & $41^{\circ} 11.600^{\prime} \mathrm{N}-41^{\circ} 50.893{ }^{\prime} \mathrm{E}$ \\
\hline
\end{tabular}




\subsection{Bitki ve Toprak Örneklerinin Hazırlanması}

Altı ölçüm istasyonundan laboratuvara getirilen toprak örnekleri kurutma kağıdı üzerine konularak bir hafta boyunca oda sıcaklığında kurumaya bırakılmıştır. Hava kurusu oluncaya kadar bekletilen örnekler $2 \mathrm{~mm}$ 'lik eleklerden elenerek homojen hale getirilmiş ve kilitli poşetlere alınarak ölçüm için hazır hale getirilmiştir (Massaquoi vd. 2015). Farklı istasyon noktalarından toplanan zeytin örneklerine ait yaprak ve meyve kısımları üç kez musluk suyu ile ardından saf su ile yıkanarak üzerindeki toz ve partiküllerden arındırılmıştır. Ardından örneklerin meyve kısımları ve iç kabukları ayrılarak petri kaplarına alınmış ve tüm numuneler $45^{\circ} \mathrm{C}$ 'de 1 hafta boyunca kurutulmuştur. Sabit tartıma gelen bitki ve meyve örnekleri bitki öğütücüde; kabuk kısımları ise kırılıp havanda dövülerek homojen hale getirilmiş ve kilitli poşetlere aktarılmıştır (Pınar 2019).

\subsection{Kimyasal Analiz}

Tüm istasyonlardan toplanan örneklerin numune türüne bağlı olarak pH, iletkenlik, elementel analiz ve ağır metal analizleri yapılarak kimyasal karakterizasyonları değerlendirilmiştir. Bu amaçla her bir istasyondan alınan toprak numunelerinden hassas terazide $10 \mathrm{~g}$ tartılarak bir erlene aktarılmış ve üzerine $25 \mathrm{~mL}$ saf su eklenerek çalkalayıcıda 105 rpm'de 30 dakika karıştırılmıştır. Karıştırılan örneklerden 15 mL'lik falkon tüplere dekantasyon yapılarak pH ve iletkenlik değerleri belirlenmiştir. pH değerinin belirlenmesinin ardından bitki, meyve, kabuk ve toprak örneklerinin \% kükürt değerleri elementel analiz cihazında ölçülmüştür. Bu amaçla toprak örneklerinden $200 \mathrm{mg}$ hassas terazide tartılarak kalay kapsüllere alınmış ve üzerine inorganik safsızlıkları gidermek amacıyla $200 \mathrm{mg}$ tungusten(VI) oksit $\left(\mathrm{WO}_{3}\right)$ eklenerek elementel analiz cihazına yerleştirilmiştir. Ardından tüm örnekler 1150 derecede yakılarak toplam \% S içerikleri belirlenmiştir. Yaprak, meyve ve kabuk örnekleri için ise aynı prosedür $100 \mathrm{mg}$ örnek ve $100 \mathrm{mg}$ tungusten(VI) oksit $\left(\mathrm{WO}_{3}\right)$ kullanılarak tekrarlanmıştır.

İstasyon noktalarında trafik kaynaklı ağır metal türleri arasından seçilen $\mathrm{Cr}, \mathrm{Ti}, \mathrm{Fe}, \mathrm{Ni}, \mathrm{Co}, \mathrm{Cu}, \mathrm{Zn}, \mathrm{Pb}, \mathrm{Al}$ ve $\mathrm{Mn}$ elementlerinin eser düzeydeki derişimlerini belirlemek amacıyla tüm örneklere mikrodalga ile yakma prosedürü uygulanmış ve gerekli seyrelmelerin yapılmasının ardından örneklerdeki metal konsantrasyonları PerkinElmer Optima 8000 ICP-OES cihazı kullanılarak belirlenmiştir. Bu amaçla ön hazırlık işlemi tamamlanmış olan her bir istasyona ait toprak numunesinden hassas terazide $0.5 \mathrm{~g}$ tartılarak teflon kaplara konulmuş ve üzerine $9 \mathrm{~mL} \mathrm{HNO}_{3}$ ve $3 \mathrm{~mL} \mathrm{HCl}$ asit karışımı eklenerek mikrodalgaya yerleştirilmiştir. 2007 yılında yayınlanan EPA 3051 (2007) mikrodalga yakma prosedürüne göre örnekler $175 \pm^{\circ} 5 C^{\prime}$ de 5.5 dakika; $180 \pm^{\circ} 5 C^{\prime}$ de 4.5 dakika bekletilmiş ve oda sıcaklığına kadar soğutulmuştur. Ardından tüm örnekler süzgeç kağıdında süzülerek son hacimleri $50 \mathrm{~mL}$ 'ye tamamlanmıştır. Farklı istasyonlardan alınan yaprak, meyve ve kabuk örneklerinde ağır metal konsantrasyonları belirlenmesi için; homojen hale getirilen her bir örnekten hassas terazide 0.3 gram tartılarak teflon kaplara aktarılmış üzerine $2 \mathrm{ml} \mathrm{HNO}_{3} \mathrm{He}^{\mathrm{mL} \mathrm{H}_{2} \mathrm{O}_{2}}$ eklenerek çeker ocakta 20 dakika bekletilmiştir. Ardından örnekler mikrodalga yakma ünitesinde $145 \pm^{\circ} 5 \mathrm{C}^{\prime} \mathrm{de} 5.5$ dakika $180 \pm^{\circ} 5 C^{\prime}$ 'de 10 dakika bekletilmiş ve oda sıcaklığına kadar soğutulmuştur. Ardından tüm örnekler süzgeç kağıdında süzülerek son hacimleri $50 \mathrm{~mL}$ 'ye tamamlanmıştır. Ön işlemleri tamamlanan tüm örnekler $0,45 \mu$ şırınga fỉltre sisteminden geçirilerek ICP-OES ile analiz için hazır hale getirilmiştir. Bitki ve toprak örneklerindeki numunelerin ağır metal konsantrasyonları belirlemek amacıyla $\mathrm{Cr}$, Ti, Fe, Ni, Co, Cu, Zn, Pb, Al ve Mn elementlerinin 1000 mg/L'lik ana stoklarından $0.02 \mathrm{mg} / \mathrm{L}$ ile $5 \mathrm{mg} / \mathrm{L}$ arasında 5 noktada kalibrasyon grafikleri çizilmiştir. Kalibrasyon grafiklerinden yararlanılarak tüm örneklerin metal konsantrasyonları belirlenmiştir. Ayrıca numune kaynaklı matriks girişimini en aza düşürmek amaciyla tüm örneklere iç standart katma yöntemi ile $1 \mathrm{mg} / \mathrm{L}$ düzeyinde Yitrium (Y) elementi katılarak örneklerin matriks etkisinden uzaklaştırılması sağlanmıştır.

Yapılan çalışmalarda analitik yöntemin doğruluğunu test etmek amacıyla toprak numuneleri için sertifikalı standart referans materyaller kullanılarak iz elementlerin metal konsantrasyonları ölçülerek geri kazanım değerleri belirlenmiştir. $\mathrm{Bu}$ amaçla toprak örneklerinde standart referans materyal LGC 6187 ve bitkide standart referans materyal ERM CD 281 kullanılmıştır.

Örneklerden elde edilen tüm veriler SPSS 19 yazılım programı kullanılarak varyans analiz (Tek yönlü anova) testi ile değerlendirilmiştir. Ölçümü yapılan örneklerin normal dağılıma uygunluğu Shapiro-wilk testi, varyansların homojenliği Levene testi ile kontrol edildikten sonra \%95 güven seviyesinde gruplar arasındaki farklılıklar Ducan testi ile ortaya konmuştur.

\section{Bulgular ve Tartışma}

İstasyon noktasından elde edilen veriler incelendiğinde, $\mathrm{pH}$ değerleri noktalar arasında 8.10-8.45 arasında değişkenlik göstermiştir. Tablo 2'den görüldüğü üzere $\mathrm{pH}$ verileri birbirine oldukça yakın değerlerde olması tüm noktalarda yer alan toprak örneklerinin hafif alkalin reaksiyonlarında olduğunu göstermektedir (Aydeniz 1985). Diğer bir parametre olan iletkenlik ölçüm sonuçlarına göre iletkenlik (EC) değerleri 277-593 $\mu \mathrm{s} / \mathrm{cm}$ arasında değişim göstermiştir. Tablo 2'ye göre en yüksek iletkenlik $593 \mu \mathrm{s} / \mathrm{cm}$ ile N2 istasyon noktasından en düşük iletkenlik ise $277 \mu \mathrm{s} / \mathrm{cm}$ ile N6 kontrol noktasından elde edilmiştir. Bu durum kirletici elementlerin toprak yüzeylerine doğru göç eğiliminde olduğunu ve bu nedenle iletkenlik değerlerinde artışa sebep verdiği sonucunu ortaya koymaktadır (Ukpaka 2016). 
Tablo 2: Toprak örnekleri için pH-iletkenlik verileri

\begin{tabular}{c|cc}
\hline Örneklem Noktaları & PH & Illetkenlik $(\boldsymbol{\mu S} / \mathbf{c m})$ \\
\hline N1 & 8.45 & 299 \\
N2 & 8.12 & 593 \\
N3 & 8.31 & 343 \\
N4 & 8.35 & 488 \\
N5 & 8.10 & 857 \\
N6 (Kontrol) & 8.41 & 277 \\
\hline
\end{tabular}

Ölçüm noktalarından alınan örneklerin elementel analiz verilerine göre toprak, yaprak, meyve ve kabuk örnekleri için \% kükürt değerleri ayrı ayrı değerlendirmiştir. Toprak örnekleri için yüzde kükürt değişimi 0.06-011 arasında, yaprak örnekleri için 0.15-0.32 arasında, meyve örnekleri için 0.11-0.22 arasında ve kabuk örnekleri için 0.09-0.25 arasında bulunmuştur.

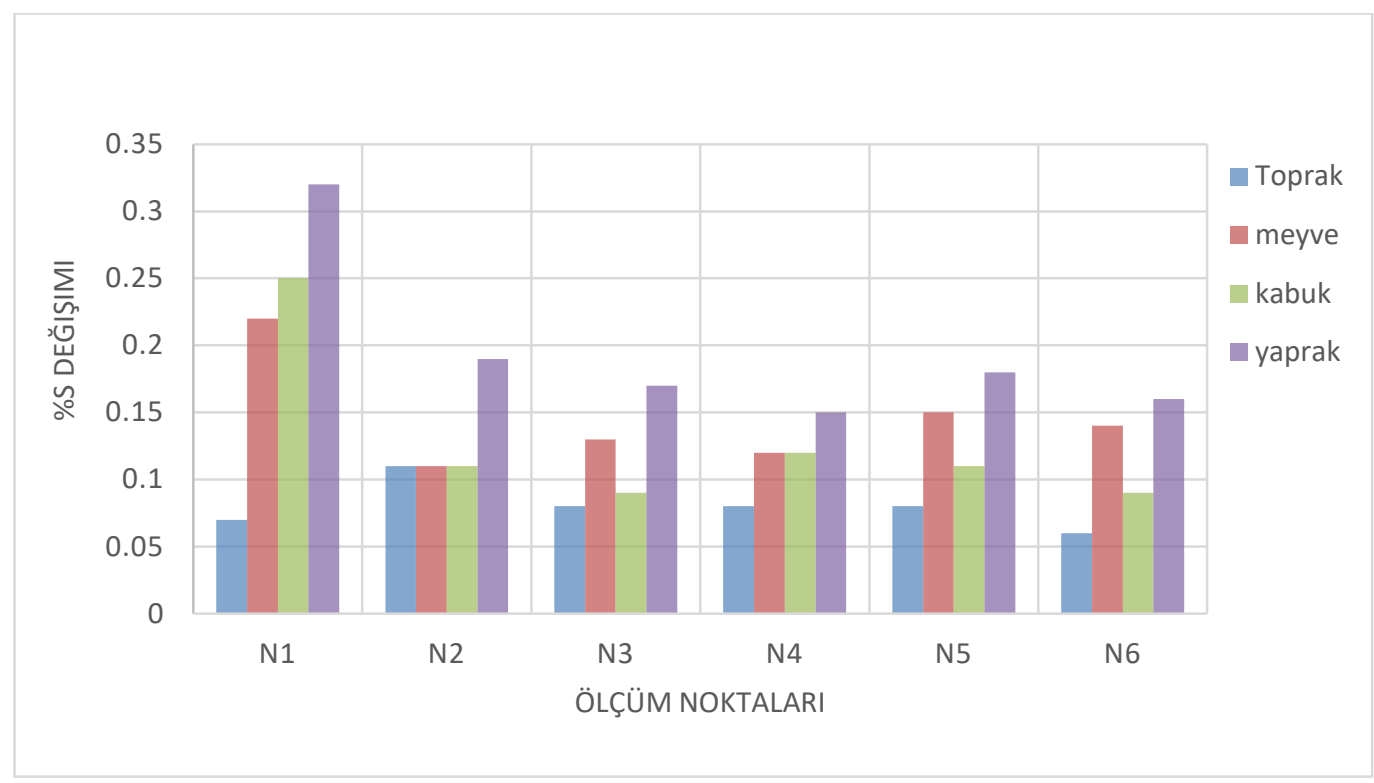

Şekil 2: Biyomonitörlerin noktalar arası \%(S) kükürt değişimi

Tablo 3: Biyomonitörlerin toprak, kabuk, meyve ve yaprakta yüzde (\%S) verileri

\begin{tabular}{l|cccc}
\hline Ölçüm Noktaları & Toprak & Yaprak & Meyve & Kabuk \\
\hline N1 & 0.07 & 0.32 & 0.22 & 0.25 \\
N2 & 0.11 & 0.19 & 0.11 & 0.11 \\
N3 & 0.08 & 0.17 & 0.13 & 0.09 \\
N4 & 0.08 & 0.15 & 0.12 & 0.12 \\
N5 & 0.08 & 0.18 & 0.15 & 0.11 \\
N6 & 0.06 & 0.16 & 0.14 & 0.09 \\
\hline
\end{tabular}

Tablo 2'de yer alan kükürt miktarlarındaki değişim için en yüksek ölçüm değeri toprakta N2 noktasında bulunmuşken, yaprak, meyve ve kabuk verileri için N1 noktasından elde edilmiştir. Bu sonuç şekil 1'den de görüldüğü üzere kentsel alanlardan uzaklaştıkça \% derişiminin azaldığını, trafik yoğunluğunun artması ile taşıt kaynaklı emisyona bağlı olarak terminal (N1) ve galeri (N2) noktalarında \% S derişiminin artığını göstermektedir (Alfani vd. 2000). Elementel analiz ölçümlerinin ardından örneklem çalışmaları öncesi metod validasyonu ve geri kazanım testleri yapılarak doğrusallık çalışmaları tamamlanmıştır. Bu çalışmalara ait veriler Tablo 4'de görülmektedir. 
Tablo 4: Referans toprak örneği için geri kazanım değerleri

\begin{tabular}{c|cccc}
\hline \multicolumn{1}{c}{ Element Adı } & $\begin{array}{c}\text { Referans Toprak } \\
\text { (LGC 6187) }\end{array}$ & $\begin{array}{c}\text { Ölçüm değeri } \\
(\mathbf{m g} / \mathbf{k g})\end{array}$ & $\begin{array}{c}\text { \% Geri } \\
\text { kazanım }\end{array}$ & \% RSD \\
\hline $\mathrm{Cr}$ & $84 \pm 1.4$ & $82.35 \pm 0.12$ & 98.03 & 0.14 \\
$\mathrm{Ti}$ & - & $401.7 \pm 13.90$ & - & 3.46 \\
$\mathrm{Fe}$ & $23600 \pm 1500$ & $23020 \pm 69.49$ & 97.50 & 0.30 \\
$\mathrm{Ni}$ & $34.7 \pm 1.7$ & $28.70 \pm 0.16$ & 82.70 & 0.55 \\
$\mathrm{Co}$ & - & $5.99 \pm 0.09$ & - & 1.50 \\
$\mathrm{Cu}$ & $83.6 \pm 4.1$ & $78.34 \pm 0.05$ & 93.70 & 0.06 \\
$\mathrm{Zn}$ & $439 \pm 26$ & $444.28 \pm 1.36$ & 101.2 & 0.30 \\
$\mathrm{~Pb}$ & $77.2 \pm 4.5$ & $54.94 \pm 4.5$ & 71.1 & 8.19 \\
$\mathrm{Mn}$ & $1240 \pm 60$ & $1082 \pm 15.89$ & 87.2 & 1.46 \\
$\mathrm{Al}$ & - & - & - & - \\
\hline
\end{tabular}

Tablo 5: Referans bitki örneği için geri kazanım değerleri

\begin{tabular}{|c|c|c|c|c|}
\hline Element Adı & $\begin{array}{l}\text { Referans Toprak } \\
\text { (ERM CD-281) }\end{array}$ & $\begin{array}{c}\text { Ölçüm değeri } \\
(\mathbf{m g} / \mathbf{k g})\end{array}$ & $\begin{array}{c}\text { \% Geri } \\
\text { kazanım }\end{array}$ & $\%$ RSD \\
\hline $\mathrm{Cr}$ & 24.8 & $21.68 \pm 0.08$ & 87.41 & 0.36 \\
\hline $\mathrm{Ti}$ & - & $1.141 \pm 0.02$ & - & 1.75 \\
\hline $\mathrm{Fe}$ & - & $113.3 \pm 0.74$ & 97.50 & 0.66 \\
\hline $\mathrm{Ni}$ & 15.2 & $13.07 \pm 0.09$ & 90.13 & 0.68 \\
\hline Co & - & ND & - & - \\
\hline $\mathrm{Cu}$ & 10.2 & $11.03 \pm 0.17$ & 108.13 & 1.54 \\
\hline $\mathrm{Zn}$ & 30.5 & $31.85 \pm 1.36$ & 104.42 & 4.27 \\
\hline $\mathrm{Pb}$ & 1.67 & $2.07 \pm 0.08$ & 123.95 & 3.86 \\
\hline Mn & 82 & $78.65 \pm 1.74$ & 95.91 & 2.41 \\
\hline $\mathrm{Al}$ & - & $10.91 \pm 0.24$ & - & 2.20 \\
\hline
\end{tabular}

*Sertifika verilerinde ölçüm yapılmamış metal konsantrasyonlarını göstermektedir.

Yapılan çalışma öncesi seçilen yöntemin analitik çalışmaya uygunluğunu belirlemek amacıyla yapılan geri kazanım değerleri toprak için Tablo 4'de bitki için Tablo 5'de ayrıntılı olarak verilmiştir. Bu çalışma ile seçilen yöntemin doğruluğu ve ölçüm sonuçlarının kesinliği test edilmiştir. Deneysel çalışmaya göre toprak örnekleri için geri kazanım çalışması \% 71.10-98.03 arasında, bitki örnekleri için \% 87.41-123.95 arasında bulunmuştur.

$\mathrm{Bu}$ sonuçlara göre çalışma $\mathrm{Pb}$ elementi dışında doğruluğu yüksek sonuçlar vermektedir. Çalışılan bitki örnekleri için $\mathrm{Pb}$ konsantrasyonu birçok noktada ölçüm limitinin altında bulunduğundan yöntem de herhangi bir revizyona gidilmemiştir. İstasyon noktalarından toplanan örneklerin eser element düzeyleri için belirlenen $\mathrm{Cr}, \mathrm{Ti}, \mathrm{Fe}, \mathrm{Ni}, \mathrm{Co}, \mathrm{Cu}$, $\mathrm{Zn}, \mathrm{Pb}, \mathrm{Al}$ ve $\mathrm{Mn}$ elementlerine ait ICP-OES ölçüm verileri Tablo 6'da gösterilmektedir. 
Tablo 6: Farklı istasyonlardan toplanan Zeytin (Olea europaea L.)'bitkisine ait toprak, yaprak, bitki ve kabuk örneklerindeki eser element konsantrasyonları ( $\mathrm{mg} / \mathrm{kg})$

\begin{tabular}{|c|c|c|c|c|c|c|c|}
\hline Element & Lokalite & Toprak & Yaprak & Kabuk & Meyve & $\begin{array}{l}\text { BSKD** } \\
(\mathrm{mg} / \mathrm{Kg})\end{array}$ & $\begin{array}{l}\text { TSKD** } \\
\text { (mg/kg) }\end{array}$ \\
\hline \multirow{6}{*}{$\mathrm{Cr}$} & N1 & $23.02 \pm 0.26$ & $0.34 \pm 0.03$ & ND & ND & $\begin{array}{c}30 \\
(\mathrm{FAO} 2003)\end{array}$ & 100 \\
\hline & $\mathrm{N} 2$ & $26.19 \pm 0.11$ & $2.19 \pm 0.03$ & $0.51 \pm 0.02$ & ND & & \\
\hline & N3 & $30.53 \pm 0.05$ & $0.91 \pm 0.04$ & ND & ND & & \\
\hline & N4 & $26.38 \pm 0.23$ & $0.50 \pm 0.01$ & ND & $1.10 \pm 0.04$ & & \\
\hline & N5 & $23.47 \pm 0.2$ & $0.36 \pm 0.01$ & ND & $0.29 \pm 0.008$ & & \\
\hline & N6 & $8.02 \pm 0.06$ & ND & ND & ND & & \\
\hline \multirow{6}{*}{$\mathbf{T i}$} & N1 & $361.12 \pm 0.71$ & $5.78 \pm 0.43$ & ND & ND & - & - \\
\hline & $\mathrm{N} 2$ & $217.43 \pm 0.23$ & $7.58 \pm 0.31$ & $0.81 \pm 0.06$ & ND & & \\
\hline & N3 & $346.55 \pm 2.53$ & $6.23 \pm 0.78$ & ND & $0.04 \pm 0.008$ & & \\
\hline & N4 & $132.16 \pm 0.65$ & $6.96 \pm 0.65$ & ND & $0.24 \pm 0.09$ & & \\
\hline & N5 & $215.47 \pm 0.23$ & $4.40 \pm 0.40$ & $0.90 \pm 0.013$ & $0.08 \pm 0.008$ & & \\
\hline & N6 & $22.91 \pm 0.25$ & $4.13 \pm 0.62$ & ND & $0.21 \pm 0.03$ & & \\
\hline \multirow{5}{*}{$\mathbf{F e}$} & $\begin{array}{l}\mathrm{N} 1 \\
\mathrm{~N} 2\end{array}$ & $\begin{array}{l}27450 \pm 110.90 \\
23120 \pm 72.29\end{array}$ & $\begin{array}{l}194.13 \pm 1.05 \\
262.95 \pm 1.07\end{array}$ & $\begin{array}{c}- \\
81.31 \pm 0.54\end{array}$ & $\begin{array}{c}- \\
11.46 \pm 0.06\end{array}$ & $\begin{array}{c}250 \\
\text { (Kabata- } \\
\text { Pendias } \\
2000 \text { ) }\end{array}$ & $\begin{array}{c}38000 \\
\text { (Kaçar ve } \\
\text { Katkat } \\
1999 \text { ) }\end{array}$ \\
\hline & N3 & $23860 \pm 318.73$ & $222.74 \pm 1.18$ & $34.64 \pm 0.04$ & $17.02 \pm 0.29$ & & \\
\hline & $\mathrm{N} 4$ & $22710 \pm 356.64$ & $214.53 \pm 3.58$ & $43.82 \pm 0.10$ & $13.03 \pm 0.18$ & & \\
\hline & N5 & $23970 \pm 242.46$ & $185.92 \pm 1.04$ & $85.26 \pm 0.52$ & $50.62 \pm 0.116$ & & \\
\hline & N6 & $19010 \pm 82.93$ & $110.11 \pm 1.22$ & $22.9 \pm 0.01$ & $18.28 \pm 0.53$ & & \\
\hline \multirow{6}{*}{$\mathbf{N i}$} & N1 & $17.07 \pm 0.21$ & $1.13 \pm 0.39$ & ND & ND & $\begin{array}{c}10 \\
(\text { Killç 2019) }\end{array}$ & 75 \\
\hline & $\mathrm{N} 2$ & $8.943 \pm 0.08$ & $1.47 \pm 0.06$ & $1.60 \pm 0.01$ & $0.04 \pm 0.01$ & & \\
\hline & N3 & $20.43 \pm 0.13$ & $0.66 \pm 0.05$ & $5.13 \pm 0.01$ & $0.90 \pm 0.01$ & & \\
\hline & N4 & $16.04 \pm 0.27$ & $0.38 \pm 0.08$ & $12.22 \pm 0.17$ & $0.57 \pm 0.02$ & & \\
\hline & N5 & $16.86 \pm 0.09$ & $0.23 \pm 0.06$ & $8.65 \pm 0.02$ & $0.23 \pm 0.04$ & & \\
\hline & N6 & $1.12 \pm 0.07$ & $0.14 \pm 0.01$ & $3.02 \pm 0.07$ & $0.86 \pm 0.05$ & & \\
\hline
\end{tabular}

ND: ölçüm sınırının altındaki dĕgeri göstermektedir.

*BSKD: Bazı bitki türleri için sinır konsantrasyon değerleri

**TSKD: Toprakta sınır konsantrasyon değerleri 


\section{Tablo 6'nın devamı}

\begin{tabular}{|c|c|c|c|c|c|c|c|}
\hline Element & Lokalite & Toprak & Yaprak & Kabuk & Meyve & $\begin{array}{l}\text { BSKD** } \\
\text { (mg/Kg) }\end{array}$ & $\begin{array}{l}\text { TSKD** } \\
\text { (mg/kg) }\end{array}$ \\
\hline \multirow{6}{*}{ Co } & N1 & $4.49 \pm 0.07$ & ND & ND & ND & \multirow{6}{*}{$\begin{array}{c}\text { 0.02-0.50 } \\
\text { (Schactschabel } \\
\text { ve Blume 1984) }\end{array}$} & \multirow{6}{*}{$\begin{array}{l}40 \\
\text { (Carrigan ve } \\
\text { Erwin 1951) }\end{array}$} \\
\hline & $\mathrm{N} 2$ & $2.97 \pm 0.04$ & ND & ND & ND & & \\
\hline & N3 & $4.25 \pm 0.08$ & ND & ND & ND & & \\
\hline & N4 & $3.64 \pm 0.06$ & ND & ND & ND & & \\
\hline & N5 & $3.55 \pm 0.09$ & ND & ND & ND & & \\
\hline & N6 & ND & ND & ND & ND & & \\
\hline \multirow{6}{*}{$\mathbf{C u}$} & N1 & $50.32 \pm 0.19$ & $6.436 \pm 0.71$ & ND & ND & \multirow{6}{*}{$\begin{array}{c}30 \\
(\text { Elmac1 1995) }\end{array}$} & \multirow[t]{6}{*}{140} \\
\hline & $\mathrm{N} 2$ & $48.35 \pm 0.45$ & $7.628 \pm 0.02$ & $5.81 \pm 0.02$ & $18.92 \pm 018$ & & \\
\hline & N3 & $41.71 \pm 0.09$ & $26.71 \pm 0.23$ & $8.61 \pm 0.10$ & $27.30 \pm 0.099$ & & \\
\hline & N4 & $75.62 \pm 0.24$ & $13.15 \pm 0.25$ & $9.17 \pm 0.15$ & $29.74 \pm 0.51$ & & \\
\hline & N5 & $42.94 \pm 0.42$ & $12.67 \pm 0.01$ & $7.75 \pm 0.15$ & $28.75 \pm 0.052$ & & \\
\hline & N6 & $6.74 \pm 0.15$ & $15.64 \pm 0.01$ & $3.72 \pm 0.04$ & $24.19 \pm 0.04$ & & \\
\hline \multirow{6}{*}{$\mathbf{Z n}$} & N1 & $77.39 \pm 1.31$ & $25.83 \pm 0.05$ & ND & ND & \multirow{6}{*}{$\begin{array}{c}400 \\
\text { (Tok 1997) }\end{array}$} & \multirow[t]{6}{*}{300} \\
\hline & $\mathrm{N} 2$ & $166.81 \pm .61$ & $31.11 \pm 0.01$ & $17.58 \pm 0.41$ & $9.11 \pm 0.11$ & & \\
\hline & N3 & $156.32 \pm 0.05$ & $29.15 \pm 0.50$ & $11.22 \pm 0.08$ & $12.59 \pm 0.195$ & & \\
\hline & N4 & $234.76 \pm 1.86$ & $18.01 \pm 0.01$ & $14.63 \pm 0.21$ & $17.97 \pm 0.10$ & & \\
\hline & N5 & $138.19 \pm 0.13$ & $23.34 \pm 0.04$ & $14.18 \pm 0.08$ & $15.18 \pm 0.20$ & & \\
\hline & N6 & $89.02 \pm 0.37$ & $18.29 \pm 0.06$ & $11.23 \pm 0.56$ & $11.71 \pm 0.01$ & & \\
\hline \multirow{6}{*}{$\mathbf{P b}$} & N1 & ND & $0.56 \pm 0.03$ & ND & ND & \multirow{6}{*}{$\begin{array}{c}10 \\
\text { (WHO 1989; } \\
\text { WHO 2007) }\end{array}$} & \multirow[t]{6}{*}{300} \\
\hline & $\mathrm{N} 2$ & $9.70 \pm 0.03$ & $0.27 \pm 0.11$ & ND & ND & & \\
\hline & N3 & $3.25 \pm 0.17$ & ND & ND & ND & & \\
\hline & N4 & $19.65 \pm 0.29$ & ND & ND & ND & & \\
\hline & N5 & $9.72 \pm 0.09$ & ND & ND & ND & & \\
\hline & N6 & ND & ND & ND & ND & & \\
\hline
\end{tabular}

ND: ölçüm sınırının altındaki değeri göstermektedir.

*BSKD: Bazı bitki türleri için sinır konsantrasyon değerleri

**TSKD: Toprakta sinır konsantrasyon değerleri 


\begin{tabular}{|c|c|c|c|c|c|c|c|}
\hline Element & Lokalite & Toprak & Yaprak & Kabuk & Meyve & $\begin{array}{l}\text { BSKD* } \\
(\mathrm{mg} / \mathrm{Kg})\end{array}$ & $\begin{array}{l}\text { TSKD** } \\
\text { (mg/kg) }\end{array}$ \\
\hline \multirow{6}{*}{ Mn } & N1 & $685.46 \pm 10.14$ & $17.94 \pm 0.3$ & ND & ND & \multirow[t]{6}{*}{$\begin{array}{c}400 \\
(\text { Elmac1 } \\
1995)\end{array}$} & \multirow[t]{6}{*}{1530} \\
\hline & $\mathrm{N} 2$ & $563.12 \pm 20.74$ & $17.57 \pm 0.1$ & $5.83 \pm 0.033$ & $4.13 \pm 0.01$ & & \\
\hline & N3 & $553.85 \pm 0.08$ & $23.35 \pm 0.1$ & $4.81 \pm 0.07$ & $4.35 \pm 0.04$ & & \\
\hline & N4 & $911.25 \pm 3.18$ & $15.32 \pm 0.06$ & $5.55 \pm 0.07$ & $3.68 \pm 0.06$ & & \\
\hline & N5 & $576.81 \pm 11.90$ & $25.38 \pm 0.40$ & $4.87 \pm 0.04$ & $6.49 \pm 0.03$ & & \\
\hline & N6 & $1162,23 \pm 10.32$ & $23.35 \pm 0.32$ & $7.63 \pm 0.04$ & $5.41 \pm 0.03$ & & \\
\hline \multirow{6}{*}{$\mathbf{A l}$} & $\mathrm{N} 1$ & $10000 \pm 25.46$ & $147.51 \pm 4.27$ & ND & ND & \multirow[t]{6}{*}{-} & \multirow[t]{6}{*}{-} \\
\hline & $\mathrm{N} 2$ & $10500 \pm 41.98$ & $286.72 \pm 0.49$ & ND & $7.02 \pm 0.34$ & & \\
\hline & N3 & $10060 \pm 82.24$ & $170.44 \pm 0.04$ & $5.68 \pm 0.36$ & $1.54 \pm 0.36$ & & \\
\hline & N4 & $10950 \pm 45.82$ & $166.15 \pm 5.76$ & $6.02 \pm 0.44$ & $\mathrm{ND} \pm$ & & \\
\hline & N5 & $13300 \pm 61.17$ & $121.96 \pm 0.24$ & $13.73 \pm 0.50$ & $5.35 \pm 0.32$ & & \\
\hline & N6 & $8606 \pm 31.46$ & $170.49 \pm 0.14$ & $11.36 \pm 0.56$ & $3.87 \pm 0.40$ & & \\
\hline
\end{tabular}

ND: ölçüm sınırının altındaki değeri göstermektedir.

*BSKD: Bazı bitki türleri için sınır konsantrasyon değerleri

**TSKD: Toprakta sinır konsantrasyon değerleri

Çeşitli bitki türleri ve toprak örnekleri için yapılan çalışmalar değerlendirildiğinde $\mathrm{Cr}, \mathrm{Fe}, \mathrm{Ni}, \mathrm{Co}, \mathrm{Cu}, \mathrm{Zn}, \mathrm{Pb}$ ve $\mathrm{Mn}$ için toprak örneklerine ait $(0-10 \mathrm{~cm})$ örneklemelerde ağır metal konsantrasyonları sınır değerler içerisinde kalmıştır. Bitki örnekleri açısından sınır değerler ile karşılaştırma yapıldığında $\mathrm{Cr}, \mathrm{Ni}, \mathrm{Zn}, \mathrm{Pb}, \mathrm{Mn}$ sınır değerler içerisinde kalmışken 2. ölçüm noktasında Fe sınır değerin üzerindedir. Ayrıca 3. ölçüm noktası için $\mathrm{Cu}$ değeri sınır değer içerisinde kalmasına rağmen diğer ölçüm noktalarına göre yüksek konsantrasyona sahiptir.

Ölçümü yapılan bitki örneğinin toprak, yaprak, meyve ve kabuk yönünden ağır metal konsantrasyonları incelendiğinde; Cr konsantrasyonu, toprakta $8.02-23.02 \mathrm{mg} / \mathrm{kg}$, yaprakta ND-0.51 mg/kg, kabukta ND-0.51 mg/kg ve meyvede ND-1.10 mg/kg arasında değişim gösterdiği belirlenmiştir. Elde edilen verilere göre Cr konsantrasyonu; toprak > meyve > kabuk > yaprak şeklinde sıralanmaktadır.

Ti konsantrasyonu toprakta 22.91-361.12 mg/kg, yaprakta 4.13-7.58 mg/kg, kabukta ND-0.90 mg/kg ve meyvede ND-0.24 mg/kg arasında değişim gösterdiği belirlenmiştir. Ti konsantrasyonu; toprak > yaprak > kabuk > meyve şeklinde siralanmaktadir.

Fe konsantrasyonu toprakta $19010-27450 \mathrm{mg} / \mathrm{kg}$, yaprakta $110.11-262.93 \mathrm{mg} / \mathrm{kg}$, kabukta $22.94-81.31 \mathrm{mg} / \mathrm{kg} \mathrm{ve}$ meyvede 11.46-50.62 mg/kg arasında değişim gösterdiği belirlenmiştir. Fe konsantrasyonu; toprak > yaprak > kabuk > meyve şeklinde sıralanmaktadır.

Ni konsantrasyonu toprakta $1.12-20.43 \mathrm{mg} / \mathrm{kg}$, yaprakta $0.14-1.47 \mathrm{mg} / \mathrm{kg}$, kabukta $1.60-12.22 \mathrm{mg} / \mathrm{kg}$ ve meyvede 0.04-0.90 mg/kg arasında değişim gösterdiği belirlenmiştir. Ni konsantrasyonu; toprak > kabuk > yaprak > meyve şeklinde sıralanmaktadır.

$\mathrm{Cu}$ konsantrasyonu toprakta $6.74-75.62 \mathrm{mg} / \mathrm{kg}$, yaprakta $06.43-26.71 \mathrm{mg} / \mathrm{kg}$, kabukta $0-9.17 \mathrm{mg} / \mathrm{kg}$ ve meyvede 18.92-29.74 mg/kg arasında değişim gösterdiği belirlenmiştir. Cu konsantrasyonu; toprak > meyve > yaprak > kabuk şeklinde sıralanmaktadır.

Co konsantrasyonu toprakta ND-4.49 mg/kg bulunurken, yaprakta, kabukta ve meyvede ölçüm değerlerinin altında olduğundan tespit edilememiştir.

Zn konsantrasyonu toprakta $77.39-234.76 \mathrm{mg} / \mathrm{kg}$, yaprakta $18.29-31.11 \mathrm{mg} / \mathrm{kg}$, kabukta $11.22-17.58 \mathrm{mg} / \mathrm{kg} \mathrm{ve}$ meyvede 9.11-17.97 mg/kg arasında değişim gösterdiği belirlenmiştir. Zn konsantrasyonu; toprak > yaprak > meyve > kabuk şeklinde sıralanmaktadır. 
$\mathrm{Pb}$ konsantrasyonu toprakta ND-19.65 mg/kg, yaprakta $0.56 \mathrm{mg} / \mathrm{kg}$, kabukta ve meyvede ölçüm değerlerin altında değişim gösterdiği belirlenmiştir. Pb konsantrasyonu; toprak > yaprak > meyve > kabuk şeklinde sıralanmaktadır.

Mn konsantrasyonu toprakta 553.85-1162.23 mg/kg, yaprakta 17.57-25.38 mg/kg, kabukta 4.81-7.63 mg/kg arasinda ve meyvede 3.68-6.49 mg/kg arasında değişim gösterdiği belirlenmiştir. Mn konsantrasyonu; toprak > yaprak > kabuk > meyve şeklinde sıralanmaktadır.

Al konsantrasyonu toprakta $8606-10950 \mathrm{mg} / \mathrm{kg}$, yaprakta $121.96-286.72 \mathrm{mg} / \mathrm{kg}$, kabukta ND-13.73 mg/kg ve meyvede ND-7.02 mg/kg arasında değişim gösterdiği belirlenmiştir. Mn konsantrasyonu; toprak > yaprak > kabuk > meyve şeklinde sıralanmaktadır.

Elde edilen verilerin sınır değerlerle karşılaştırılması, bitki türüne ve toprak yapısına göre değişiklik göstereceğinden verilerin varyansları istatiksel olarak karşılaştırılmıştır. İstatiksel olarak yapılan çalışmada ilk olarak toprak örneği için varsyansların homojenliği karşılaştırılmıştır. Bu amaçla yapılan Levene testine göre tüm metal türleri için sig. değeri 0.05 ten büyük olduğu için varyanslar homojenliği sağlanmıştır. Yapılan varyans analizine göre türler arasındaki farklılıklar tüm noktalar için istatiksel olarak anlamlı bulunmuştur $(\mathrm{p}<0.05)$. Noktalar arasındaki farklılığın hangi gruplar arasında olduğunu belirlemek amacıyla Duncan testi yapılmış ve sonuçlar Tablo 7'de verilmiştir.

Tablo 7: Toprak örnekleri için farklı noktalar arasındaki ağır metal konsantrasyonların değişimi (n:5 ölçüm)

\begin{tabular}{l|llllll}
\hline $\begin{array}{l}\text { Örneklem } \\
\text { (Toprak) }\end{array}$ & 1.nokta & $2 . n o k t a$ & 3.nokta & 4.nokta & 5.nokta & $\begin{array}{c}\text { 6.nokta } \\
(\text { Kontrol) }\end{array}$ \\
\hline$C r$ & $23.02 \pm 0.26^{\mathrm{b}}$ & $26.19 \pm 0.11^{\mathrm{c}}$ & $30.53 \pm 0.05^{\mathrm{d}}$ & $26.38 \pm 0.23^{\mathrm{c}}$ & $23.47 \pm 0.2^{\mathrm{b}}$ & $8.02 \pm 0.06^{\mathrm{a}}$ \\
$\mathrm{Ti}$ & $361.12 \pm 0.71^{\mathrm{a}}$ & $217.43 \pm 0.23^{\mathrm{b}}$ & $346.55 \pm 2.53^{\mathrm{c}}$ & $132.16 \pm 0.65^{\mathrm{d}}$ & $215.47 \pm 0.23^{\mathrm{e}}$ & $22.91 \pm 0.25^{\mathrm{f}}$ \\
$\mathrm{Fe}$ & $27450 \pm 110.90^{\mathrm{a}}$ & $23120 \pm 74.29^{\mathrm{b}}$ & $23860 \pm 318.73^{\mathrm{a}}$ & $22710 \pm 356.64^{\mathrm{a}}$ & $23970 \pm 2421.46^{\mathrm{a}}$ & $19010 \pm 82.93^{\mathrm{c}}$ \\
$\mathrm{Ni}$ & $17.07 \pm 0.21^{\mathrm{a}}$ & $8.943 \pm 0.08^{\mathrm{b}}$ & $20.43 \pm 0.13^{\mathrm{a}}$ & $16.04 \pm 0.27^{\mathrm{a}}$ & $16.86 \pm 0.09^{\mathrm{a}}$ & $1.12 \pm 0.007^{\mathrm{c}}$ \\
$\mathrm{Co}$ & $4.49 \pm 0.07^{\mathrm{a}}$ & $2.97 \pm 0.04^{\mathrm{b}}$ & $4.25 \pm 0.08^{\mathrm{a}}$ & $3.64 \pm 0.06^{\mathrm{a}}$ & $3.55 \pm 0.09^{\mathrm{a}}$ & $\mathrm{ND}$ \\
$\mathrm{Cu}$ & $50.32 \pm 0.19^{\mathrm{a}}$ & $48.35 \pm 0.45^{\mathrm{b}}$ & $41.71 \pm 0.09^{\mathrm{c}}$ & $75.62 \pm 0.24^{\mathrm{d}}$ & $42.94 \pm 0.42^{\mathrm{e}}$ & $6.74 \pm 0.15^{\mathrm{f}}$ \\
$\mathrm{Zn}$ & $77.39 \pm 1.31^{\mathrm{a}}$ & $166.81 \pm 3.61^{\mathrm{b}}$ & $156.32 \pm 0.05^{\mathrm{c}}$ & $234.76 \pm 1.86^{\mathrm{d}}$ & $138.19 \pm 0.13^{\mathrm{e}}$ & $89.02 \pm 0.37^{\mathrm{f}}$ \\
$P b$ & $\mathrm{ND}$ & $9.70 \pm 0.03^{\mathrm{a}}$ & $3.25 \pm 0.17^{\mathrm{b}}$ & $19.65 \pm 0.29^{\mathrm{c}}$ & $9.72 \pm 0.09^{\mathrm{d}}$ & $\mathrm{ND}^{\mathrm{a}}$ \\
$\mathrm{Al}$ & $10000 \pm 25.46^{\mathrm{a}}$ & $10500 \pm 31.98^{\mathrm{b}}$ & $10060 \pm 32.24^{\mathrm{a}}$ & $10950 \pm 45.82^{\mathrm{c}}$ & $13300 \pm 52.17^{\mathrm{d}}$ & $8606 \pm 31.46^{\mathrm{e}}$ \\
$\mathrm{Mn}$ & $685.46 \pm 10.14^{\mathrm{a}}$ & $563.12 \pm 20.74^{\mathrm{b}}$ & $553.85 \pm 0.08^{\mathrm{c}}$ & $911.25 \pm 3.18^{\mathrm{d}}$ & $576.81 \pm 11.90^{\mathrm{e}}$ & $1162.23 \pm 10.32^{\mathrm{f}}$ \\
\hline
\end{tabular}

*ND: ölçüm aralı̆ğnın dışında olduğunu göstermektedir. Yatay olarak metal konsantrasyonları üzerinde kullanılan harfler istasyonlar arsındaki fark ifade etmekte olup, farkl harfler ile gösterilen ortalamalar istatistiksel olarak anlamlı bir fark olduğunu göstermektedir ( $p<0.05$ ).

Tablo 7'den görüldüğü üzere toprak örnekleri için Duncan testi sonuçları değerlendirildiğinde aynı harf ile temsil edilen noktalar ortalamaları arasında anlamlı bir fark olmadığı tespit edilmiştir. Bu sonuçlara göre Cr için en yüksek konsantrasyon $30.53 \pm 0.053 \mathrm{mg} / \mathrm{kg}$ ile 3 nolu istasyonda en düşük konsantrasyon ise $8.02 \pm 0.06 \mathrm{mg} / \mathrm{kg}$ ile 6 nolu kontrol istasyonundan elde edilmiştir. Ti için; en yüksek konsantrasyon $361.12 \pm 0.71 \mathrm{mg} / \mathrm{kg}$ ile 1 nolu istasyondan en düşük konsantrasyon $22.91 \pm 0.25 \mathrm{mg} / \mathrm{kg}$ ile 6 nolu kontrol istasyonundan elde edilmiştir. Fe için; en yüksek konsantrasyon $27450 \pm 110.90 \mathrm{mg} / \mathrm{kg}$ ile 1 nolu istasyondan en düşük konsantrasyon $19010 \pm 0.25 \mathrm{mg} / \mathrm{kg}$ ile 6 nolu kontrol istasyonundan elde edilmiştir. Ni için; en yüksek konsantrasyon $20.43 \pm 0.13 \mathrm{mg} / \mathrm{kg}$ ile 3 nolu istasyondan en düşük konsantrasyon $1.12 \pm 0.007 \mathrm{mg} / \mathrm{kg}$ ile 6 nolu kontrol istasyonundan elde edilmiştir. Co için; en yüksek konsantrasyon $4.49 \pm 0.07 \mathrm{mg} / \mathrm{kg}$ ile 1 nolu istasyondan en düşük konsantrasyon 6 nolu kontrol istasyonundan elde edilmiştir. $\mathrm{Cu}$ için en yüksek konsantrasyon $75.62 \pm 0.24$ ile 4 nolu istasyondan en düşük konsantrasyon $6.74 \pm 0.15$ ile 6 nolu kontrol istasyonundan elde edilmiştir. Zn için en yüksek konsantrasyon $234.76 \pm 1.86$ ile 4 nolu istasyondan en düşük konsantrasyon $77.39 \pm 1.31$ ile 1 nolu istasyonundan elde edilmiştir. 4.49 \pm 0.07 . Pb için; en yüksek konsantrasyon $19.65 \pm 0.29^{\mathrm{c}} \mathrm{mg} / \mathrm{kg}$ ile $4 \mathrm{nolu}$ istasyondan en düşük konsantrasyon 1 ve 6 nolu istasyonlardan elde edilmiştir. Al için en yüksek konsantrasyon $13300 \pm 52.17$ ile 5 nolu istasyondan en düşük konsantrasyon 8606 \pm 31.46 ile 6 nolu kontrol istasyonundan elde edilmiştir. Mn için en yüksek konsantrasyon $1162.23 \pm 10.32$ ile 6 nolu kontrol istasyonundan en düşük konsantrasyon $553.85 \pm 0.08$ ile 3 nolu kontrol istasyonundan elde edilmiştir. Elde edilen bu veriler; istatiksel olarak değerlendirildiğinde; kontrol noktasına göre bütün gruplar farklı harf aldıklarından ortalamalar arasındaki anlamlı bir fark vardır $(p<0.05)$. Ayrıca Ti, $\mathrm{Cu}, \mathrm{Zn}, \mathrm{Pb}$ ve $\mathrm{Mn}$ için bütün istasyon noktalarındaki ölçüm değerleri farklı harflerle simgelenmiştir. Bu durum noktalar arasında istatiksel olarak anlamlı bir fark olduğunun kanıtıdır $(p<0.05)$. Farklı noktalardan alınan toprak örneklerindeki ağır metal konsantrasyonlarına ait veriler; dünyadaki farklı şehirlerde yapılan çalışmalarla karşılatılmış ve Tablo 8'de verilmiştir.

Dünyada ve ülkemizde trafik kaynaklı ağır metal kirliliği için yapılan çalışmalar ve kontrol noktasındaki deneysel veriler incelendiğinde trafik yoğunluğuna bağlı olarak 0-10 cm'den alınan toprak örnekleri için ağır metal konsantrasyonları $\mathrm{Ti}, \mathrm{Ni}, \mathrm{Cu}$ ve $\mathrm{Pb}$ yönünden kontrol noktasına göre 10 katı kadar artış göstermekte iken $\mathrm{Co}$ ve $\mathrm{Cr}$ yönünden 3 kat artış göstermiştir. Bu durum Artvin örneğinin diğer birçok çalışmadaki konsantrasyonlara paralellik gösterdiğini ve kirletici etmenlerden birisinin de trafik yoğunluğu olduğu sonucunu ortaya koymaktadır (Knezevic vd. 2009; Möller vd. 2004; Sezgin vd. 2003). Tablo 9'da bitki örnekleri için noktalar arası karşılaştırmalarda Cr için en yüksek konsantrasyon $2.19 \pm 0.03 \mathrm{mg} / \mathrm{kg}$ ile 2 nolu istasyondan en düşük $4.13 \pm 0.62 \mathrm{~m}$ konsantrasyon 6 nolu istasyondan elde edilmiştir. Ti için; için en yüksek konsantrasyon $7.58 \pm 0.31 \mathrm{mg} / \mathrm{kg}$ ile 2 nolu istasyondan en düşük konsantrasyon $4.13 \pm 0.62 \mathrm{mg} / \mathrm{kg}$ ile 6 nolu istasyondan elde edilmiştir. 
Fe için en yüksek konsantrasyon $262.95 \pm 1.07 \mathrm{mg} / \mathrm{kg}$ ile 2 nolu istasyondan en düşük konsantrasyon $110.11 \pm 1.22 \mathrm{mg} / \mathrm{kg}$ ile 6 nolu istasyondan elde edilmiştir. Co için tüm veriler ölçüm değerlerinin altında kalmıştır. Cu için en yükssek konsantrasyon $26.71 \pm 0.23 \mathrm{mg} / \mathrm{kg}$ ile 3 nolu istasyondan en düşük konsantrasyon $6.436 \pm 0.71 \mathrm{mg} / \mathrm{kg}$ ile 1 nolu istasyondan elde edilmiştir. Zn için en yüksek konsantrasyon $31.11 \pm 0.01 \mathrm{mg} / \mathrm{kg}$ ile 2 nolu istasyondan en düşük konsantrasyon $18.01 \pm 0.01 \mathrm{mg} / \mathrm{kg}$ ile 4 nolu istasyondan elde edilmiştir. Al için en yüksek konsantrasyon $286.72 \pm 0.49 \mathrm{mg} / \mathrm{kg}$ ile $2 \mathrm{nolu}$ istasyondan en düşük konsantrasyon $147.51 \pm 4.27 \mathrm{mg} / \mathrm{kg}$ ile 1 nolu istasyondan elde edilmiştir. Mn için en yüksek konsantrasyon $25.38 \pm 0.40 \mathrm{mg} / \mathrm{kg}$ ile 5 nolu istasyondan en düşük konsantrasyon $17.57 \pm 0.1 \mathrm{mg} / \mathrm{kg}$ ile 2 nolu istasyondan elde edilmiştir. Elde edilen bu veriler; istatiksel olarak değerlendirildiğinde; kontrol noktasına göre bütün gruplar farklı harf aldıklarından ortalamalar arasındaki anlamlı bir fark vardır $(p<0.05)$.

Tablo 8: Dünyada ve ülkemizde trafik kaynaklı ağır metal içeriklerinin belirlenmesi için yapılan çalışmalar

\begin{tabular}{|c|c|c|c|c|c|c|c|c|c|c|c|}
\hline Şehir/Ülke & $\begin{array}{l}\mathrm{Cr} \\
\mathrm{mg} / \mathrm{kg}\end{array}$ & $\begin{array}{l}\mathrm{Ti} \\
\mathrm{mg} / \mathrm{kg}\end{array}$ & $\begin{array}{l}\mathrm{Fe} \\
\mathrm{mg} / \mathrm{kg}\end{array}$ & $\begin{array}{l}\mathrm{Ni} \\
\mathrm{mg} / \mathrm{kg}\end{array}$ & $\begin{array}{l}\mathrm{Co} \\
\mathrm{mg} / \mathrm{kg}\end{array}$ & $\begin{array}{l}\mathrm{Cu} \\
\mathrm{mg} / \mathrm{kg}\end{array}$ & $\begin{array}{l}\mathrm{Zn} \\
\mathrm{mg} / \mathrm{kg}\end{array}$ & $\begin{array}{l}P b \\
\mathrm{mg} / \mathrm{kg}\end{array}$ & $\begin{array}{l}A l \\
\mathrm{mg} / \mathrm{kg}\end{array}$ & $\begin{array}{l}M n \\
m g / k g\end{array}$ & Literatür \\
\hline $\begin{array}{l}\text { Shanx } \\
\text { (Çin) }\end{array}$ & - & - & - & 23 & - & 71 & 32 & 30 & - & - & $\begin{array}{l}\text { (Pan vd. } \\
\text { 2016) }\end{array}$ \\
\hline $\begin{array}{l}\text { HongKong } \\
\text { (Japonya) }\end{array}$ & 23.10 & - & - & 12.40 & - & 23.30 & 125 & 94.60 & & & (Li vd. 2004) \\
\hline $\begin{array}{l}\text { Toronto } \\
\text { (kanada) }\end{array}$ & 558 & - & 70050 & 327 & - & 392.1 & 1367.8 & 378.7 & - & 3125 & $\begin{array}{l}\text { (Nazzal vd. } \\
\text { 2014) }\end{array}$ \\
\hline $\begin{array}{l}\text { Galwey } \\
\text { (irlanda) }\end{array}$ & 33.3 & 1643 & 1.7 & 22 & 5.6 & 33.2 & 99.3 & 78.4 & 1.2 & 674 & (Zhang 2006) \\
\hline $\begin{array}{l}\text { Palermo } \\
\text { (Italya) }\end{array}$ & 39.00 & - & - & 19.10 & - & 77.00 & 151.00 & 253.0 & - & 566.0 & $\begin{array}{l}\text { (Manta vd. } \\
\text { 2002) }\end{array}$ \\
\hline $\begin{array}{l}\text { Eskişehir } \\
\text { (Türkiye) }\end{array}$ & 97.65 & - & 19149 & 161.53 & - & 39.33 & 31.50 & 64.93 & - & 395.7 & $\begin{array}{c}\text { (Malkoc vd } \\
\text { 2010) }\end{array}$ \\
\hline $\begin{array}{l}\text { Kayseri } \\
\text { (Türkiye) }\end{array}$ & 23.5 & - & 22830 & 23.7 & - & 15.8 & 56.3 & 17.9 & - & 494 & $\begin{array}{c}\text { (Yalçın vd. } \\
\text { 2007) }\end{array}$ \\
\hline $\begin{array}{l}\text { Artvin } \\
\text { örneği } \\
\text { (Türkiye) }\end{array}$ & 22.93 & 215.8 & 23353 & 13.41 & 3.15 & 44.27 & 143.71 & 7.05 & 10569 & 742.0 & \\
\hline
\end{tabular}

Tablo 9: Yaprak örnekleri için farklı noktalar arasındaki ağır metal konsantrasyonların değişimi (n:3 ölçüm)

\begin{tabular}{|c|c|c|c|c|c|c|}
\hline $\begin{array}{l}\text { Örneklem } \\
\text { (Yaprak) }\end{array}$ & N1 & $N 2$ & N3 & N4 & N5 & N6 \\
\hline $\mathrm{Cr}$ & $0.34 \pm 0.03^{\mathrm{a}}$ & $2.19 \pm 0.03^{b}$ & $0.91 \pm 0.04^{\mathrm{c}}$ & $0.50 \pm 0.01^{\mathrm{d}}$ & $0.36 \pm 0.01^{\mathrm{e}}$ & ND \\
\hline $\mathrm{Ti}$ & $5.78 \pm 0.43^{\mathrm{a}}$ & $7.58 \pm 0.31^{\mathrm{b}}$ & $6.23 \pm 0.78^{c}$ & $6.96 \pm 0.65^{\mathrm{d}}$ & $4.40 \pm 0.40^{\mathrm{e}}$ & $4.13 \pm 0.62^{\mathrm{e}}$ \\
\hline $\mathrm{Fe}$ & $194.13 \pm 1.05^{\mathrm{a}}$ & $262.95 \pm 1.07^{b}$ & $222.74 \pm 1.18^{c}$ & $214.53 \pm 3.58^{d}$ & $185.92 \pm 1.04^{\mathrm{e}}$ & $110.11 \pm 1.22^{f}$ \\
\hline$N i$ & $1.13 \pm 0.39^{\mathrm{a}}$ & $1.47 \pm 0.06^{\mathrm{b}}$ & $0.66 \pm 0.05^{\mathrm{c}}$ & $0.38 \pm 0.08 \mathrm{~d}$ & $0.23 \pm 0.06 \mathrm{e}$ & $0.14 \pm 0.01 \mathrm{f}$ \\
\hline Co & ND & ND & ND & ND & ND & ND \\
\hline $\mathrm{Cu}$ & $6.436 \pm 0.71^{\mathrm{a}}$ & $7.628 \pm 0.02^{\mathrm{b}}$ & $26.71 \pm 0.23^{c}$ & $13.15 \pm 0.25^{\mathrm{d}}$ & $12.67 \pm 0.01^{\mathrm{e}}$ & $15.64 \pm 0.01^{\mathrm{f}}$ \\
\hline$Z n$ & $25.83 \pm 0.05^{\mathrm{a}}$ & $31.11 \pm 0.01^{\mathrm{b}}$ & $29.15 \pm 0.50^{c}$ & $18.01 \pm 0.01^{\mathrm{d}}$ & $23.34 \pm 0.04^{\mathrm{e}}$ & $18.29 \pm 0.06^{\mathrm{d}}$ \\
\hline $\mathrm{Pb}$ & $0.56 \pm 0.03^{\mathrm{a}}$ & $0.27 \pm 0.11^{\mathrm{b}}$ & ND & ND & ND & ND \\
\hline$A l$ & $147.51 \pm 4.27^{\mathrm{a}}$ & $286.72 \pm 0.49^{b}$ & $170.44 \pm 0.04^{\mathrm{c}}$ & $166.15 \pm 5.76^{d}$ & $121.96 \pm 0.24^{\mathrm{e}}$ & $170.49 \pm 0.14$ \\
\hline$M n$ & $17.94 \pm 0.3^{\mathrm{ab}}$ & $17.57 \pm 0.1^{\mathrm{ab}}$ & $23.35 \pm 0.1^{\mathrm{c}}$ & $15.32 \pm 0.06^{\mathrm{ad}}$ & $25.38 \pm 0.40^{\mathrm{e}}$ & $23.35 \pm 0.32^{\mathrm{e}}$ \\
\hline
\end{tabular}

*ND: ölçüm aralığının dışında olduğunu göstermektedir. Yatay olarak metal konsantrasyonları üzerinde kullanılan harfler istasyonlar arasındaki farkı ifade etmekte olup, farklı harfler ile gösterilen ortalamalar istatiksel olarak anlamlı bir fark olduğunu göstermektedir ( $p<0.05)$.

Farklı noktalardan alınan zeytin (Olea europaea L.) yaprağı örneklerindeki ağır metal konsantrasyonlarına ait veriler; dünyadaki farklı şehirlerde yapılan çalışmalarla karşılatılmış ve Tablo 10'da verilmiştir.

Tablo 10'dan görüldüğü üzere yaprakta ağır metal birikimin Dünya ve Türkiye'de yapılan çalışmalarla karşılaştırıldığında; $\mathrm{Cr}$ yönünden orta düzeyde kirlilik, $\mathrm{Pb}$ yönünden düşük düzeyde kirlilik göstermişken diğer bütün elementlerde konsantrasyonların yapılan çalışmaların üzerinde olduğu gözlemlenmiştir.

Farklı noktalardan alınan zeytin (Olea europaea L.) meyvesi örneklerindeki ağır metal konsantrasyonlarına ait veriler karşılaştırmalı olarak Tablo11'de verilmiştir. 
Tablo 10: Dünyada ve ülkemizde trafik kaynaklı ağır metal içeriklerinin belirlenmesi için yapılan çalışmalar

\begin{tabular}{|c|c|c|c|c|c|c|c|c|c|c|c|}
\hline $\begin{array}{l}\text { Örnek } \\
\text { Türü̈ }\end{array}$ & $\begin{array}{l}\mathrm{Cr} \\
\mathrm{mg} / \mathrm{kg}\end{array}$ & $\begin{array}{l}T i \\
m g / k g\end{array}$ & $\begin{array}{l}\mathrm{Fe} \\
\mathrm{mg} / \mathrm{kg}\end{array}$ & $\begin{array}{l}N i \\
m g / k g\end{array}$ & $\begin{array}{l}\mathrm{Co} \\
\mathrm{mg} / \mathrm{kg}\end{array}$ & $\begin{array}{l}\mathrm{Cu} \\
\mathrm{mg} / \mathrm{kg}\end{array}$ & $\begin{array}{l}\mathrm{Zn} \\
\mathrm{mg} / \mathrm{kg}\end{array}$ & $\begin{array}{l}P b \\
m g / k g\end{array}$ & $\begin{array}{l}A l \\
m g / k g\end{array}$ & $\begin{array}{l}\mathrm{Mn} \\
\mathrm{mg} / \mathrm{kg}\end{array}$ & Literatür \\
\hline $\begin{array}{l}\text { Zeytin } \\
\text { yapră̆ı } \\
\text { Aydın } \\
\text { (Türkiye) }\end{array}$ & 22 & - & 7.67 & - & - & 2.65 & - & 27 & 7.92 & 1.40 & (Turan vd. 2011) \\
\hline $\begin{array}{l}\text { Zeytin } \\
\text { yaprağl } \\
\text { (Tunus) }\end{array}$ & 0.4 & - & - & - & - & 1.31 & 3.9 & - & - & - & (Zaanouni vd. 2018) \\
\hline $\begin{array}{l}\text { Zeytin } \\
\text { Yaprak } \\
\text { Kazdağları } \\
\text { (Türkiye) }\end{array}$ & 0.7 & - & 9.6 & 0.4 & - & 1.2 & 0.9 & - & - & 1.7 & (Kılıç 2020) \\
\hline $\begin{array}{l}\text { Zeytin } \\
\text { Yaprak } \\
\text { Artvin } \\
\text { (Türkiye) }\end{array}$ & 2.19 & 7.58 & 262.9 & 1.47 & - & 26.7 & 31.1 & 0.6 & 286.7 & 25.4 & \\
\hline
\end{tabular}

Tablo 11: Ülkemizde trafik kaynaklı ağır metal içeriklerinin belirlenmesi için yapılan çalışmalar

\begin{tabular}{|c|c|c|c|c|c|c|c|c|c|c|c|}
\hline $\begin{array}{l}\text { Örnek } \\
\text { Türü̈ }\end{array}$ & $\begin{array}{l}\mathrm{Cr} \\
\mathrm{mg} / \mathrm{kg}\end{array}$ & $\begin{array}{l}T i \\
m g / k g\end{array}$ & $\begin{array}{l}\mathrm{Fe} \\
\mathrm{mg} / \mathrm{kg}\end{array}$ & $\begin{array}{l}\mathrm{Ni} \\
\mathrm{mg} / \mathrm{kg}\end{array}$ & $\begin{array}{l}\mathrm{Co} \\
\mathrm{mg} / \mathrm{kg}\end{array}$ & $\begin{array}{l}\mathrm{Cu} \\
\mathrm{mg} / \mathrm{kg}\end{array}$ & $\begin{array}{l}\mathrm{Zn} \\
\mathrm{mg} / \mathrm{kg}\end{array}$ & $\begin{array}{l}\mathrm{Pb} \\
\mathrm{mg} / \mathrm{kg}\end{array}$ & $\begin{array}{l}A l \\
\mathrm{mg} / \mathrm{kg}\end{array}$ & $\begin{array}{l}M n \\
m g / k g\end{array}$ & Literatür \\
\hline $\begin{array}{l}\text { Zeytin } \\
\text { meyve } \\
\text { Kazdağlart } \\
\text { (Türkiye) }\end{array}$ & 0.7 & - & 9.6 & 0.4 & - & 1.2 & 0.9 & - & - & 1.7 & (Kılıç 2020) \\
\hline $\begin{array}{l}\text { Zeytin } \\
\text { Meyve } \\
\text { Bursa } \\
\text { (Türkiye) }\end{array}$ & 0.59 & - & 7.08 & 0.37 & 0.06 & 0.78 & 10.58 & 0.75 & 7.02 & - & (Şahan vd. 2007) \\
\hline $\begin{array}{l}\text { Zeytin } \\
\text { Meyve } \\
\text { Artvin } \\
\text { (Türkiye) }\end{array}$ & 0.5 & - & 50.62 & 0.86 & - & 29.74 & 17.97 & - & 7.02 & 6.49 & \\
\hline
\end{tabular}

Artvin çalışması için istasyonlardan alınan örneklerle diğer çalışmalar karşılaştırıldığında $\mathrm{Fe}, \mathrm{Ni}, \mathrm{Cu}$ ve $\mathrm{Mn}$ konsantrasyonlarının yüksek olduğu görülmektedir (Kılıç 2020).

\section{Sonuç ve Öneriler}

Sonuç olarak yapılan çalışmada toprak örnekleri için; trafiğe yakın bölgelerdeki alanlardan alınan örneklerindeki tüm metal konsantrasyonlar sınır değerlerin içerisinde yer almaktadır. Ancak, kentleşme ve trafik kaynaklı kirlilikten uzak olan kontrol noktasından alınan örneklere göre karayolu üzerinden alınan tüm örneklerde $\mathrm{Cr}, \mathrm{Ti}, \mathrm{Fe}, \mathrm{Ni}, \mathrm{Co}, \mathrm{Cu}$ ve $\mathrm{Pb}$ konsantrasyonun yüksek çıkması trafik kaynaklı ağır metal kirliliği bulgusunu desteklemektedir (Şişman 1999). Çalışmanın biyomonitör üzerinden ağır metal birikimi incelendiğinde; çok yıllık bitkilerin yaprak yüzeylerinde biriken ağır metallerin stomota, kitükiler ve çatlaklar gibi kanallardan bitkide absorblanmakta ve yıllar içerisinde ağır metal birikimi olarak karşımıza çıktığı görülmektedir (Shahid vd. 2017). Bu bitkilerin yapraklarındaki metal birikimine ait kimyasal kompozisyon incelendiğinde; 3 temel kirletici grubu karşımıza çıkmaktadır. Bunlardan toprak kaynaklı matriks elementleri olanlar ( $\mathrm{Si}, \mathrm{Al}, \mathrm{Fe}, \mathrm{Mg}, \mathrm{N}, \mathrm{S}, \mathrm{Ca}, \mathrm{K}, \mathrm{Cl}$ ); yakıt kaynaklı matriks elementleri olanlar (Al, Si, Ca, Ni, Fe, V ve $\mathrm{Pb}$ ) ve kömür kaynaklı matriks elementleri olanlar (C, Al, Si, K, Ca) olarak sınıflandırılabilir. Yapılan çalışma ve ölçüm değerleri incelendiğinde; yakıt kaynaklı matriks elementleri arasında Al ve Fe değerinin trafik yoğunluğuna bağlı olduğu alanlarda kontrol noktasına göre yüksek olduğu ICP-OES ile tespit edilmiş ve istatiksel testlerle de ayrıntılı olarak gösterilmiştir (Tomasevic ve Anicic 2010). Bu durum trafik yoğunluğu ve kentleşmenin fazla olduğu alanlardan uzaklaştıkça bitkilerdeki ağır metale bağlı biyoakümülasyonun azaldığını göstermektedir. 
Çalışmanın son basamağı olan meyve ve kabuk çalışması bitkide akümüle olan antrojenik kaynaklı ağır metalin yer küreden canlı organizmaya taşınmasındaki basamağı göstermektedir. Her ne kadar meyve örneklerindeki ağır metal birikimi belirlenen örnek çalışmalardan görüldüğü üzere sınır değerlerin içerisinde yer alsa da $\mathrm{Cr}$ ve $\mathrm{Al}$ yönünden kontrol noktasına göre yüksek değerler tespit edilmiştir. Ayrıca zeytin meyvelerindeki Cu konsantrasyonları yapılan birçok çalışmada 0.73-3.55 mg/kg arasında tespit edilmesine rağmen; (Şahan vd. 2007) örneklem noktalarından alınan örneklerde $26.7 \mathrm{mg} / \mathrm{kg} \mathrm{Cu}$ derişimi elde edilmiştir. Bu metal konsantrasyonlarındaki yüksekliğin sebebi; trafik kaynaklı kirliliklerinin dışında, bölgenin coğrafi ve jeolojik yapısı ile toprağın maden zuhurları bakımından zengin olması olabilir. Bu nedenle gıda kaynaklı metal konsantrasyonlarına bağlı olarak kontamine olan gıda ürünlerinin günlük sınır değerinin dişında tüketimi sonucu vücutta akümüle olarak toksik etki gösterebilmektedir (Dökmeci ve Dökmeci 2005).

\section{Teşekkür}

Çalışmanın yürütüldüğü ve analizlerinin değerlendirildiği Artvin Çoruh Üniversitesi Bilim Teknoloji Uygulama ve Araştırma Merkezine katkılarından dolayı teşekkür ederim.

\section{Kaynaklar}

Aksoy A., Hale W.H., Dixon J.M., (1999), Capsella bursa-pastoris (L.) Medic. as a biomonitor of heavy metals, Science of the Total Environment, 226(2-3), 177-186.

Alfani A., Baldantoni D., Maisto G., Bartoli G., De Santo A.V., (2000), Temporal and spatial variation in C, N, S and trace element contents in the leaves of Quercus ilex within the urban area of Naples, Environmental Pollution, 109(1), 119-129.

Altın V., (2002), Yenilenebilir enerji kaynaklar, TÜBİTAK Bilim-Teknik Dergisi-Yeni Ufuklara Eki, 410, 2-23.

Aydeniz A., (1985), Toprak Amenajman, Ankara Üniversitesi, Ziraat Fakültesi Yayınları: 928, Ankara.

Barnes D., Hamadah M.A., Ottaway J.M., (1976), The lead, copper and zinc content of tree rings and bark A measurement of local metallic pollution, Science of the Total Environment, 5(1), 63-67.

Bayram H., Dörtbudak Z., Fişekçi F.E., Kargın M., Bülbül B., (2006), Hava kirliliğinin insan sağlı̆̆ına etkileri, dünyada, ülkemizde ve bölgemizde hava kirliliği sorunu, Dicle Tıp Dergisi, 33(2), 105-112.

Bingham E., Cohrssen B., Powell C.H., (2001), Toxicological Issues Related to Metals: Neurotoxicology and Radiation Metals and Metal Compounds, Wiley-Interscience, New York, USA, 819ss.

Bondada B.R., Tu S., Ma L.Q., (2004), Absorption of foliar-applied arsenic by the arsenic hyperaccumulating fern (Pteris vittata L.), Science of the Total Environment, 332(1-3), 61-70.

Carrigan R.A., Erwin T.C., (1951), Cobalt determination in soils by spectrographic analysis following chemical preconcentration, Soil Science Society of America Journal, 15(C), 145-149.

Dökmeci İ., Dökmeci A.H., (2005), Toksiloji zehirlemede tanı ve tedavi, 4. Baskı, Nobel Tıp Kitapevleri, İstanbul, Türkiye.675ss.

Efe R., Soykan A., Sönmez S., Cürebal İ., (2009), Sicaklık şartlarının Türkiye'de zeytinin (Olea europea L. subs. europaea) yetişmesine, fenolojik ve pomolojik özelliklerine etkisi, Ekoloji, 18 (70), 17-26.

Elmac1 Ö.L., (1995), Güney Marmara Bölgesi sanayi domates alanlarındaki toprak sulama suyu ve domates (Lycopersicum esculentum) meyvelerinde ă̆ır metal içeriklerinin belirlenmesi, Doktora Tezi, Ege Üniversitesi, Fen Bilimleri Enstitüsü, İzmir.

EPA, (2007), Method 3051A (SW-846): Microwave assisted acid digestion of sediments, sludges, and Oils, Revision 1, https://www.epa.gov/sites/production/files/2015-12/documents/3051a.pdf, [Erişim 9 Temmuz 2020].

FAO, (2003), Codex Alimentarius Commission adopts more than 50 new food standards, http://www.fao.org/english/newsroom/news/ 2003/20363-en.html, FAO Newsroom, [Erişim 1 Temmuz 2020].

Ferreire I.C.F.R., Barros L., Soares M.E., Bastos M.L., Pereira J.A., (2007), Antioxidant Activity and Phenolic Contents of Olea europaea L. Leaves Sprayed with Different Copper Formulations, Food Chemistry, 103, 188-195.

Kabata-Pendias, A.,2000, Trace element in soils and plants, 3rd edition, CRC Press, USA, 413ss.

Kaçar B., Katkat A.V., (1999), Gübreler ve gübreleme tekniği, Uludağ Üniversitesi Güçlendirme Vakfi Yayınları, Bursa, Türkiye, $401 \mathrm{ss}$

Karaca A., Turgay O.C., (2012), Toprak kirliliği, Toprak Bilimi ve Bitki Besleme Dergisi, 1(1), 13-19.

Keçeli T., Gordon M.H. (2002)., Ferric ions Reduce the Antioxidant Activity of the Phenolic Fraction of Virgin Olive Oil, Journal of Food Science, 67(3), 943-947.

Knezevic M., Stankovic D., Krstic B., Nikolic M.S., Vilotic D., (2009), Concentrations of heavy metals in soil and leaves of plant species Paulownia elongata SY Hu and Paulownia fortunei Hemsl, African Journal of Biotechnology, 8(20), 5422-5429.

K1lıç D.D., (2019), Investigation of heavy metal accumulation and biomonitoring of Calepina irregularis species growing in Amasya (Turkey) province, Anatolian Journal of Botany, 3(2), 44-50.

Kılıç S., (2020), Kazdağları Bölgesine Ait Zeytin, Zeytin Yaprağı ve Zeytinyağlarının Element Tayini ve Metot Validasyonu, Eurasian Journal of Biological and Chemical Sciences, 3(1), 48-54.

Kiritsakis A.K., (1998), Flavor components of olive oil-A review. Journal of the American Oil Chemists' Society, 75(6), 673-681.

Li X., Lee S.L., Wong S.C., Shi W., Thornton I., (2004), The study of metal contamination in urban soils of Hong Kong using a GIS-based approach, Environmental Pollution, 129(1), 113-124.

Malkoc S., Yazıc1 B., Savas Koparal A., (2010), Assessment of the levels of heavy metal pollution in roadside soils of Eskisehir, Turkey, Environmental Toxicology and Chemistry, 29(12), 2720-2725.

Manta D.S., Angelone M., Bellanca A., Neri R., Sprovieri M., (2002), Heavy metals in urban soils: a case study from the city of Palermo (Sicily), Italy, Science of the Total Environment, 300(1-3), 229-243. 
Massaquoi L.D., Ma H., Liu X.H., Han P.Y., Zuo S.M., Hua Z.X., Liu D.W., (2015), Heavy metal accumulation in soils, plants, and hair samples: an assessment of heavy metal exposure risks from the consumption of vegetables grown on soils previously irrigated with wastewater, Environmental Science and Pollution Research, 22(23), 18456-18468.

Mater B., (1998), Toprak coğrafyası, Çantay Kitabevi, İstanbul, Türkiye, 271ss.

Möller A., Müller H.W., Abdullah A., Abdelgawad G., Utermann J., (2005), Urban soil pollution in Damascus, Syria: concentrations and patterns of heavy metals in the soils of the Damascus Ghouta, Geoderma, 124(1-2), 63-71.

Nazzal Y., Ghrefat H., Rosen M. A., (2014), Heavy metal contamination of roadside dusts: a case study for selected highways of the greater Toronto area, Canada involving multivariate geostatistics, Research Journal of Environmental Sciences, 8(5), 259-273.

Pan L.B., Ma J., Wang X.L., Hou H., (2016), Heavy metals in soils from a typical county in Shanxi Province, China: levels, sources and spatial distribution, Chemosphere, 148, 248-254.

Pınar B., (2019), Bazı peyzaj bitkilerinde ağır metal birikiminin trafik yoğunluğuna bă̆lı değişimi, Doktora Tezi, Kastamonu Üniversitesi, Fen Bilimleri Enstitüsü, Kastamonu.

Sayılı M., Akman Z., (1994), Tarımsal uygulamalar ve çevreye olan etkileri, Ekoloji Dergisi, 12(7), 28-32.

Sezgin N., Ozcan H.K., Demir G., Nemlioğlu S., Bayat C., (2003), Determination of heavy metal concentrations in street dusts in Istanbul E-5 Highway, Environment International, 29, 973-985.

Schactschabel P, Blume H.P., (1984), Lehrbuch der Bodenkunde. Enke, Stuttgart, Almanya, 441ss.

Sresty T.V.S., Rao K.M., (1999), Ultrastructural alterations in response to zinc and nickel stress in the root cells of pigeonpea, Environmental and Experimental Botany, 41(1), 3-13.

Şahan Y., Basoglu F., Gücer S., (2007), ICP-MS analysis of a series of metals (Namely: $\mathrm{Mg}, \mathrm{Cr}$, Co, $\mathrm{Ni}, \mathrm{Fe}, \mathrm{Cu}, \mathrm{Zn}, \mathrm{Sn}, \mathrm{Cd}$ and $\mathrm{Pb}$ ) in black and green olive samples from Bursa, Turkey, Food Chemistry, 105(1), 395-399.

Shahid M., Dumat C., Khalid S., Schreck E., Xiong T., Niazi N.K., (2017), Foliar heavy metal uptake, toxicity and detoxification in plants: A comparison of foliar and root metal uptake, Journal of hazardous materials, 325, 36-58.

Şişman İ., (1999), Sapanca bölgesinde TEM otoyolundan kaynaklanan ağır metal kirliliği, Yüksek Lisans Tezi, Sakarya Üniversitesi, Fen Bilimleri Enstitüsü, Sakarya.

Turan D., Kocahakimoglu C., Kavcar P., Gaygisız H., Atatanir, L., Turgut C., Sofuoglu S. C., (2011), The use of olive tree (Olea europaea L.) leaves as a bioindicator for environmental pollution in the Province of Aydin, Turkey, Environmental Science and Pollution Research, 18(3), 355-364.

TÜIK, (2019), Türkiye'de katılı toplam motorlu kara tașıtı sayısı istatistikleri, Türkiye İstatistik Kurumu, https://data.tuik.gov.tr/ Bulten/Index?p=Motorlu-Kara-Tasitlari-Aralik-2019-33648, [Erişim:30 Ocak 2020].

Tok H.H., (1997), Çevre Kirliliği, Anadolu Matbaası, İstanbul, 404ss.

Tomašević M., Aničić M., (2010), Trace element content in urban tree leaves and sem-edax characterization of deposited particles, Facta Universitatis-Series: Physics, Chemistry and Technology, 8(1), 1-13.

Ukpaka C.P., (2016), Empirical model approach for the evaluation of pH and conductivity on pollutant diffusion in soil environment, Chemistry International, 2(4), 267- 278.

WHO, (1989), Evaluation of certain food additives and contaminants: Thirty-third report of the Joint FAO/WHO Expert Committee on food additives, World Health Organization, WHO technical report series, no. 776, WHO, Geneva (1989), 66ss.

WHO, (2007), WHO guidelines for assessing quality of herbal medicine with reference contaminants and residues, World Health Organization, Spain, 105ss.

Yalcin M.G., Battaloglu R., Ilhan S., (2007), Heavy metal sources in Sultan Marsh and its neighborhood, Kayseri, Turkey, Environmental Geology, 53(2), 399-415.

Yanık T., Atamanalp M., (2001), Balık yetiştiriciliğinde su kirliliğine giriş, Atatürk Üniversitesi Ziraat Fakültesi, Ders Yayınları No: 226, Erzurum.

Zaanouni N., Gharssallaoui M., Eloussaief M., Gabsi S., (2018), Heavy metals transfer in the olive tree and assessment of food contamination risk, Environmental Science and Pollution Research, 25(19), 18320-18331.

Zhang C., (2006), Using multivariate analyses and GIS to identify pollutants and their spatial patterns in urban soils in Galway, Ireland, Environmental Pollution, 142(3), 501-511. 